\title{
Turkish Culinary Culture In The Socialization Process
}

\section{Sosyalizasyon Sürecinde Türk Mutfak Kültürü}

Prof. Dr. Ferah OZKOK

Canakkale Onsekiz Mart University

Faculty of Tourism

E-posta:fozkok@comu.edu.tr

Orcid Id: 0000-0002-7085-6117

\section{Assist.Prof.Dr. Serdar SUNNETCIOGLU \\ Canakkale Onsekiz Mart University \\ Faculty of Tourism \\ E-posta:serdarsunnetcioglu@comu.edu.tr Orcid Id: 0000-0003-0244-5874}

\author{
Lecturer Ayse SUNNETCIOGLU \\ Canakkale Onsekiz Mart University \\ Vocational School of Ezine \\ E-posta: aysesunnetcioglu@comu.edu.tr \\ Orcid Id: 0000-0002-4295-9776 \\ PhD. Student Ezgi KARAKAS \\ Canakkale Onsekiz Mart University \\ Institute of Social Sciences \\ E-posta: ezgisucu@hotmail.com \\ Orcid Id: 0000-0002-2413-5036
}

\begin{abstract}
Socialization can be defined as process whereby cultural components are passed down from one generation to the other. Socialization as a process lays down the guidelines of a food culture (as in religion rules, manners and customs, etc.) and renovates itself by undergoing a transformation process with each and every interaction. Relying on the review of the existing studies into Turkish culture, the present paper attempts to describe how Turkish culinary culture has been transferred from one generation to the other and how Turkish cuisine has taken shape within the socialization process. The study is based on a conceptual framework, but fails to support the results with empirical data. As the result of the literature review, a conceptual model is proposed. In the model, Turkish cuisine is examined in three dimensions, which are analytical dimension, descriptive dimension, and historical dimension.
\end{abstract}

Keywords: Cuisine, Turkish cuisine, Socialization, Socialization process, Gastronomy.

\section{Öz}

Sosyalizasyon, kültürel unsurları geçmişten günümüze, günümüzden de geleceğe aktaran süreç olarak tanımlanabilir. Sosyalizasyon süreci kültürel unsurları geçmişten günümüze, günümüzden de geleceğe aktarırken bir yandan yemek kültürü için bir sınır çizmekte (din kuralları, örf ve adetler, gelenekler gibi), bununla birlikte diğer taraftan her yeni açılımla bir dönüşüm sürecine girerek kendini yeniden üretmektedir. Bu çalışmayla Türk mutfak kültürünün nesilden nesile nasıl aktarıldığı sosyalizasyon olgusu ile açıklanmaya çalışılmış, Türk mutfağının sosyalizasyon süreci içerisinde nasıl şekillendiği, Türk mutfağı ile ilgili yapılan çalışmalar incelenerek ele alınmıştır. Çalışma kavramsal bir çalışma olup, ampirik veriler ile desteklenememesi çalışmanın önemli bir sınırılığını oluşturmaktadır. Yapılan literatür taraması sonucunda kavramsal bir model sunulmuştur. Bu modele göre Türk Mutfağı, çözümsel boyut, betimsel boyut ve tarihsel boyut olmak üzere üç boyutta ele alınmıştır.

Anahtar Kelimeler: Mutfak kültürü, Türk mutfağı, Sosyalizasyon, Sosyalizasyon süreci, Gastronomi. 


\section{Introduction}

In oral tradition, no folk literature text or form can remain unchanged and be handed down from generation to generation as it is. Similarly, besides the way food is consumed and the rules that must be followed, how ancestral foods are cooked or served significantly varies these days (Azadovski, 2002: 1). Briefly, cultural facts never remain stable, but are always in motion (Abdurrezak, 2005). Culinary culture is considered as the tangible reflection of the intangible cultural heritage. Therefore, no cuisine remains stable, but it always renovates itself (Okumuş et al., 2007: 254 ; McKrecher et al., 2008: 138; Çevik and Saçılık, 2011 : 504-505 ). This dynamic process results from socialization. Most of gastronomic situations, e.g. eating styles or nutritional habits, are shaped during the socialization process (Beşirli, 2010: 168). Based on the statements of Ercan (2013: 35), newborn children could not explore fire and how to cook if they did not undergo a socialization process. It is stated that individuals start to socialize during infancy and breastfeeding period through the culinary culture a baby is born into (Beardsworth and Keil, 2011). Additionally, through Ercan's (2013:35) definition of socialization period, it could be said that socialization draws a line for food culture as religion rules, manners and customs, etc. and also renovates itself as it expands by going through a transformation process. Local food culture is considered as a cultural heritage of destination (McKrecher et al., 2008; Okumuş et al., 2007), a sign of culture, a symbol of a certain region (Lin et al., 2011), a tangible reflection of intangible cultural heritage (Çevik and Saçılık, 2011: 504-505; McKrecher, 2008: 138; Okumuş and et al., 2007: 254), a destination identity (Horng et al., 2012: 40) and the mirror of a society (Sağır, 2012: 2678).

It is stated that infrastructural causes and elements become invisible when culture and cultural elements are regarded as still images. Therefore, culture or cultural factors should be deemed as living creatures and watched as if seeing a movie. To find the foundation (or the basic steps) of cultural elements, it is necessary to conduct diachronic research from the earliest dates onwards (Kapağan, 2013: 802). Among the phenomena that can provide some insight into this matter is nutrition. Beşirli (2010) notes that nutrition is not only a biological act but also a cultural phenomenon. However, there is little interest in this issue since many researchers generally consider feeding as a biological action (Beşirli, 2010: 159). Therefore, it is aimed in this research to present how food and beverages, their preparations, cooking style, storage, necessary equipment, eating habits, developments and beliefs of Turkish culinary culture are shaped in the socialization process from anthropologic point of view.

\section{The Concept of Socialization}

Individuals have always lived in a society/community throughout history. Since people live together, they interact with each other, which in return leads to the "birth" of common values. Thus, each society has a peculiar conception of life and life style. Societies shaped by specific customs and judgments have to hand their cultural system down from generation to generation in order to survive. Such assignments and transfers are achieved through the adaptation of individuals to the forms and styles of an organized social life (Coştu, 2009: 117-118). Socialization is defined as the process of being a human in the broadest sense. Accordingly, socialization process consists of creation of personal identity, cultural transfer, learning how to behave in a relevant social environment and adaptation to social norms and values (Bozkurt, 2007: 112; Beardsworth and Keil, 2011: 94). In other words, socialization is the process of learning societal rules, values and attitudes, behaving accordingly and developing an 
identity in a society (İçli, 2002: 91). Moreover, socialization can be also defined as the interaction process while adapting to the norms, values, attitudes and characteristic language of groups of individuals. It is also expressed that socialization is referred to as a learning process for individuals who are new in a different culture (Oskay, 1974: 93).

There are two ways to discuss socialization: primary and secondary socialization. Primary socialization is defined as the process of socialization from childhood to adulthood through primary groups of parents, friends and neighbors. In this process, principle values and norms in a socialized culture are introduced to individuals. On the other hand, secondary socialization requires continuous adaptation to constantly renewed culture. It is achieved via educational institutions (Oskay, 1974: 94-95). In another conceptualization, socialization is described from two perspectives. The first type is defined as subjective socialization, which denotes a learning process whereby individuals adapt to people around. The second one is objective socialization, which refers to the adaption process of individuals by which society culture is handed down from generation to generation and individuals adapt to the accepted practices of organized social life. The function of objective socialization is to improve necessary social abilities and rules. Thus, it is assumed that individuals adapt to living values and purposes and learn social roles which should be fulfilled in the society (Fichter, 1973: 29). Socialization process may be summarized as learning and teaching cultural elements through communication with society (Yılmaz, 2013: 321).

Coştu (2009: 120) states that socialization is described in different ways by different disciplines. For instance, anthropologists define socialization as a process of intergenerational cultural transfer, whereas psychologists identify socialization as an acquisition of individual development skills. Besides, the science of sociology emphasizes that socialization is the development of such aspects as knowledge, skills and attitudes that allow them to adapt to a given social environment. On the other hand, political socialization is mainly shaped by political behaviors and directions and focuses on such processes as citizenship education.

The analysis of the existing research on the concept of socialization has revealed that they are generally discussed from an anthropological, political, administrative and marketing point of view. To exemplify, Kulmbach (2014) analyzes the formation of food socialization in early childhood. The examination of anthropological approaches has shown that nutrition and food finding strategies serve as determinants in the formation of social structures and of different social types (Beşirli, 2010: 161). In political socialization studies, Beşirli (2005) considers the concept of military service as a part of the political socialization, whereas Yeşilorman (2006) examines the role of socioeconomic factors in the political socialization process. In the studies on socialization, management and business science too are frequently compared. In these studies, socialization is generally associated with such issues as organizational adaptation of employees and increase in employees' efficiency (Van Maanen and Schein, 1979; Çalık, 2003; Sökmen, 2007; Memduhoğlu, 2008; Çerik and Bozkurt, 2010; Zorlu and Kara, 2012; Pelit and Kahyaoğlu, 2015). Moreover, the effects of socialization on transformational leadership are among the research subjects (Gupta and Hrishman, 2004). Even in the marketing field, the concept of socialization is a research subject in the context of client socialization (Ward, 1974; Moschis and Churchill, 1978; Moschis et al., 1984; Dotson and Hyatt, 2005). Besides, the effects of media and communication tools on socialization are also among the most researched topics (Dubow et al., 2006; Prot et al., 2015). 
In all of the studies mentioned above, socialization is described through the introduction of culture to people or integration people into a culture. In this research, it is aimed to explain how Turkish culinary culture is handed down from generation to generation based on the concept of socialization and from an anthropologic viewpoint.

\section{Food, Beverage and Turkish Culinary Culture in Socialization Process}

In this study, the model developed by Ercan (2013) to demonstrate the basic components of social structure is utilized and adapted for the purpose of the study as in Figure -1 . The primary concern is to explain how Turkish cuisine is shaped within the socialization process in consideration of the related literature. As previously mentioned, the process of handing societal culture down from generation to generation is called as socialization. Like every other society, the Turkish society too has gone through and been shaped in this process. In this regard, it is considered that the use of the model developed by Ercan (2013) will prove adequate to investigate how the Turkish culinary culture is shaped in the socialization process. In order to describe Turkish culinary culture in the socialization process, the related literature on Turkish cuisine was reviewed. As a result of literature review, three dimensions, which are mentioned in Ercan's (2013) model, were discovered.

Figure 1: The Model for Food and Beverages and Turkish Culinary Culture in Socialization Period

\begin{tabular}{|c|c|c|}
\hline $\begin{array}{l}\text { Analytical } \\
\text { Dimension }\end{array}$ & & $\begin{array}{l}\text { - Human - Nature Relation: Physiological Dimension of } \\
\text { Turkish Cuisine } \\
\text { - Human - Human Relation: Cultural Dimension of } \\
\text { Turkish Cuisine }\end{array}$ \\
\hline $\begin{array}{l}\text { Descriptive } \\
\text { Dimension } \\
\text { (Tangible Forms } \\
\text { of Turkish } \\
\text { Cuisine) }\end{array}$ & & $\begin{array}{l}\text { - Location: Geography, Dining areas } \\
\text { - Social Structure: Sharing food, Table manners } \\
\text { - Values and Beliefs: Religion, Traditions, Customs }\end{array}$ \\
\hline $\begin{array}{c}\text { Historical } \\
\text { Dimension } \\
\text { (Historical } \\
\text { Stages of } \\
\text { Turkish Cuisine) }\end{array}$ & $\longrightarrow$ & $\begin{array}{l}\text { - } \text { Nomadism } \\
\text { - Acceptance of Islam } \\
\text { - Agricultural society period, Settled life in Anatolia, } \\
\text { Ottoman Period }\end{array}$ \\
\hline
\end{tabular}

Source: Adapted from Ercan, F. (2013). "Toplumlar ve Ekonomiler." Ankara: Bağlam Press.

\subsection{Analytical Dimension}

Gürsoy (2014) claims that human existence and the relation between human and food are of the same age. Besides the fact that learning to 'eat' is natural, turning it into 'food' is stated as an achievement through experience and hard work; the improvement; the life style and human - geography relation. Ercan (2013: 43) defines 
it within the scope of human - nature relation. According to Ercan (2013), humans have been obliged to establish relationship with nature from the first moments of their lived in order to fulfill their needs. On one hand, human is the part of nature; on the other hand, he is the only living creature conflicting with nature to safeguard its existence. The most basic requirement of humankind is nutrition as stated by Gürsoy (2014: 16). Moreover, Özgen (2013) defines that nutrition is the only condition to survive. In order to retrieve food and beverage, humans have had to struggle with wild animals and natural conditions as well as themselves. Nutrition retrieval is achieved through collecting plants, fruits, and vegetables (Özgen, 2013: 2). This occurred in the Paleolithic Era (B.C. 600.000 - 10.000) (Erbay, 2006: 43). Afterwards, humankind discovered the fire and then has warmed and protected themselves and learned to cook. Based on the archeological investigations, the first cooking methods were to cook in dry heat as in frying, roasting and fumigation (Özgen, 2013: 2-3). To sum up, humans had to establish relations with nature from the very beginning in order to meet their nutritional and hydrational needs. In other words, people have benefited from nature to satisfy their needs (Ercan, 2013: 43). Childe (2010: 20) expresses that mouflon has adapted to live in a cold mountain climate by acquiring its thick sheepskin, whereas humans have adapted to live in the same environment by making woolen clothes. Rabbits dig pits in the ground with their nails and noses to build a shelter against the cold and their enemies, whereas humans construct similar shelters with pickaxe and shovel. Lions have claws and teeth for hunting, whereas humans make arrows and spears for the same purpose. The following period, which is also named Mesolithic, is known as the Epipaleolithic Era (B.C. 10.000 - 8000). In this period, similar climatic conditions to the current ones started to emerge and the Ice Age ended. Moreover, plants and animals changed back then. Instead of large and slow animals, smaller and quicker animals emerged. Then, hunters started to create smaller hunting tools. Bow and arrow were invented in this period. Moreover, different kinds of stones and scythes were utilized to reap wild plants (Erbay, 2006: 144). It is stated that hunting-gathering societies communed with ecosystem. Furthermore, it is emphasized that this integration was destroyed with the advent of agricultural practices (Emiroğlu, 2012: 22). In the relation between human and nature, nature was directly manipulated by people to survive in the previous period. However, Mesolithic period necessitated the use of intermediary tools as arrows, spears and slings. In this sense, the important point for this research is that people hunted animals by inventing arrows, spears and slings in order to adapt to the nature and to survive. Thus, food and beverage retrieval period continued with hunting. Ercan (2013: 43) summarizes this situation as the humanization of nature by people as well as of themselves.

Nutrition is a biological activity. Based on that, it is defined as the satisfaction of the physiological needs of human metabolism, e.g. energy and food (Beşirli, 2010: 159). It is the root cause underlying the relation between human and nature; survival instinct. The relation between human and nature is essentially based on social characteristics. The conversion of nature is a social activity. Besides, the main feature of this social activity is the relationship between people (Ercan, 1995: 15). Therefore, nutrition is not only a biological activity but also a cultural fact (Beşirli, 2010: 159; Güneş et al., 2008: 5; Abdurrezak, 2005). Food is a tangible fact although culture of food is formed with the established relations (Halıcı, 2010: 151). Culinary culture consists of preparing the types of food and beverage, cooking, consuming and storing. Moreover, location, equipment, food and beverage tradition, religion and cultural structure are the components of a culinary culture (Durlu-Özkaya, Cömert and Kızılkaya, 2009: 266). 
The culinary culture based on flavor was developed in the Neolithic Era (B.C. $8000-6000)$. This period is also defined as the last part of the Stone Age. In this period, people started to establish villages or cities, to adopt a sedentary life, and to be productive. Hunting was improved and dog became the first domesticated animal. Sheep and goat were domesticated towards the end of this period (Erbay, 2006: 45).

\subsection{Descriptive Dimension}

Cultural factors are formed and changed in a historical process and socio-physical environment (Aksoy, 1998: 38). It is possible to explain the socio-physical environment with geography of culinary. Experienced geography is called 'terroir' in French by Petrini (2001), which is defined as the creation of original character from the combination of natural (ground, air, altitude above sea level, vegetation and microclimates) and human factors (traditions and cultivation forms) to grow and cook food in every field. "Kitchen" is defined as a physical field where food is prepared, cooked and also consumed. However, kitchen is the part of a culture at the same time (Aktaş and Özdemir, 2007: 3). Moreover, table is valued as a socialization tool (Beşirli, 2010: 166). Both sitting at the table and sharing the food are defined as the outcomes of socialization process. Besides, these outcomes are accepted as the indicators of cultural characteristics of a community. It is defined that individuals learn their social status and roles as well as the religious values through socialization (Beşirli, 2010: 168). For example, in the legend of Oghuz Khan, which part of a sheep will be eaten by which clan is clearly stated. In order to prevent any conflict between clans and Turks, assignment of the parts to be eaten by clans was declared as a custom. It is the view of the system called "ülüş" (sharing) in Turkish culture. Sharing meat is the expression of appreciation for the government and law in a broader sense. It is possible to say that customs have always had the highest importance in Turkish culture throughout history including Islamic periods. Turkish community life has been organized based on customs. In moorland life, customs were more effective than religion. The influence of social degeneration on moorland is more dramatic than that of sedentary society. In fact, the smallest division or internal conflict created significant results. Because the most important power on moorland is productive people, manpower is essential to all areas from economy to military. A corrupted social order means loss of labor force. Therefore, social life should be regulated by strict rules on moorlands. These rules are much stricter than those of the religions accepted by Turks. For instance, the punishment for robbery was death in Turkish society, whereas a lighter penalty was executed in other societies during the period of moorland culture. There were many similar enforcements in moorland laws since the force that kept the moorland societies alive was authority. However, the boundaries of religion and manners were not fused and one did not become superior to the other (Inan, 1998: 247-254).

Mevlevi cuisine can be shown as a good example of the conceptualization of table as a socialization tool. After Turkish Culture of the Central Asia had become Islamic in Anatolia, new and different sects such as 'Ahi, Bektashism, Mevlevi and Khalenderism' emerged. In Ottoman period, the Mevlevi Culture became more important than the other sects (Çakır, 2005: 356). The influence of Mevlevi Cuisine on Turkish cuisine is observable in Konya cuisine (Tapur, 2009: 478). The most important part of Mevlevis' houses is 'matbah', where the food is cooked and eaten. The prospective members of Mevlevi are mostly educated in this place. Therefore, Mevlevis also call 'matbah' as the place where people are "cooked" to transcend (Uzun, 2015: 271 ). It is emphasized that kitchen play quite an important role in sophism/mysticism. The purpose is not only cooking but also teaching to respect the 
food served by nature with extraordinary effort. Mevlevi kitchen is also named as 'Mevlevi Somad' and eating is accepted as a kind of worship in Mevlevi culture (semazen.net).

\subsection{Historical Dimension}

Turkish people identified the moorland between the Ural Mountains and the Altay Mountains in Central Asia as their homeland. Nomadic life with horses too emerged in this geography. Their food consists of pastry from wheat flour, milk and other dairy products, and horse and sheep meat and their drink was "Kımız", which is made from milk of mare (Kosay, 1982: 47). They benefited from naturally raised animal and grown plants of the region, where they migrate (Baysal, 2002: 29).

At the end of the Neolithic Era (B.C. $6000-5500$ ), humankind started to make pottery with clay, which was used to store and transport liquid and solid food. In this period, people began to produce and store grain. Catalhoyuk in Konya is a typical settlement of this period (Erbay, 2006: 46). Gürsoy (2014) states that the production of wheat, barley, lentils, peas and bean was improved in this period. It is also stated that cereal grains were crushed by beating with mallet and their bran was separated on the grinding stone. Copper is the first processed metal since it can be processed at a low temperature and easily shaped by beating. The most important characteristic of the Chalcolithic Era (B.C. $5500-3000$ ) is that stone tools were replaced by copper tools. In this period, also called the Copper Era, barley and wheat was produced and dogs, sheep, goats, cattle and donkeys were raised, and horses were domesticated to be used in caravan trade. The first signs, called the origin of cuneiform, were found in this period (Erbay, 2006: 47).

In the Bronze Era (B.C. 3000 - 1200), pottery production and ceramics trade increased. Thus, communities got richer. In order to protect their wealth, cities with walls, palaces, temples, and granaries were created. The social structure changed and kings became dominant (Erbay, 2006: 48).

Turkish cuisine having started to take shape during the journeys of nomadic Turks from Asia to Anatolia originated from a long historical development (Özgen, 2013: 9). While Turkish nomads were passing from Asia to Anatolia, They converted to Islam, which has quite a remarkable role in the shaping of not only the Turkish history but also the Turkish cuisine. After Islam was accepted, pork and meats and milk of donkey, horse, hinny, and animals having single toe, forbidden by The Holy Quran, were never cooked in Turkish cuisine (Güler, 2010: 25; Ertaş and Karadağ, 2013:117). Moreover, feeding or eating pork is incongruent with Islamic codes since pork can be feed only by the people leading a sedentary life but not by nomads based on the available research. However, the effects of traditional culture and belief should still be considered (Kılıç and Albayrak, 2012: 710). For example, the influence of Arabic cuisine increased on the food of southeastern Anatolia with the advent of Islam, in which so many spices have came to be used (Ertaş and Karadağ, 2013: 119 adapted from Baysal et al., 1996). Another influence of Islam on Turkish cuisine is the recitation of "bismillah" before having dinner and of "Elhamdülillah" denoting "being thankful to God" (Güler, 2010: 28).

After the $11^{\text {th }}$ and $12^{\text {th }}$ centuries, religious institutions have become an indispensible part of social life. Thus, Islamic praying areas too became the kitchen of public (Sürücüoğlu and Özçelik, 2005: 12). In this period, it was observable that the influence of Mevlevi philosophy on Turkish cuisine was eminent. Settlement in Anatolia 
is regarded as a milestone of Turkish culinary culture (Özgen, 2013: 9). During the historical development, firstly the simple culinary culture of the Central Asia was found. Then, the rich Seljukian and Ottoman kitchen appeared. As a result, the Turkish cuisine emerged, which is acclaimed by many different cultures and consists of a rich variety of flavors (Durlu - Özkaya et al., 2009: 1).

\section{Conclusion}

Nutrition, based on food and beverages is not only a biological activity but also an act as the production of a cultural transmission. Today, it might be claimed that food and beverage preferences and eating habits and rituals in a society result from geographical, economic, cultural, religious, and political factors coming from the past.

Handing social culture down from generation to generation is called socialization. Like every society, Turkish society too has gone through a socialization process. In this study, the nutrition structure of Turkish society is handled as well as the socialization process of Turkish culinary culture. The failure to substantiate the results with empirical data can be considered as a notable limitation of the present study.

Based on the model, Turkish cuisine in socialization process was examined in three dimensions. As the first dimension, analytical dimension is discussed in two contexts: human - nature relation and human - human relation. The context of human - nature relation consists of the physiological dimension of Turkish cuisine as the retrieved products because of the relation between Turks and nature and their assessments. Besides, the context of human - human relation is concerned with the food and beverage characteristics acquired through Turks' interactions with each other and other cultures. Secondly, it was concluded in descriptive dimension that geography and dining areas form location, sharing food and table manners form social structure, and religion, traditions and customs create values and beliefs. Lastly, the historical dimension was found to consist of the most important historical events, influential in Turkish culinary culture, such as nomadism, conversion to Islam, agricultural society period, settled life in Anatolia, Ottoman period and the period after industrial revolution.

Turkish cuisine continues to change and develop due to the effects of current conditions (globalization, immigrations, etc.). This progress will become as how Turkish cuisine has been developed by all the mentioned factors above from past to present. In this sense, the important point is the transfer of Turkish culinary culture, which bears the traces of the Turkish history of thousands of years from generation to generation without being assimilated by other cultures.

The transfer of the Turkish cuisine to the next generations is important not only for sustainable gastronomy but also for gastronomic tourism, which means people travels to experience especially ethnic food. Thus, oral history studies at local, regional and national level enable us to record the descriptions of our grandparents and to passed them down to future generations as unchanged. In this context, practices to protect the Turkish cuisine and efforts to transfer it to the upcoming generations should be investigated. 


\section{References}

Abdurrezzak, A.O., (2005). Sosyo-Kültürel Bağlamda Yemek ve Illetişim, Milli Folklor, 9,(67). 1-16.

Aksoy, M. (1998), "Türkler'de At Kültürü ve Kımız". Türk Dünyası Tarih Dergisi, 142, 38-44.

Aktaş, A. and Özdemir, B. (2007). Otel Işsletmelerinde Mutfak Yönetimi. Ankara: Detay Yayıncılık.

Azadovski, M. (2002) "Giriş”, Sibirya'dan Bir Masal Anası (Çev. İlhan Başgöz), Kültür Bakanlığı, Genişletilmiş İkinci Baskı, Ankara,

Baysal, A. (2002), "Beslenme Kültürümüz" T.C. Ministry of Culture Editions: 1230, Yayımlar Dairesi Başkanlığı Kültür Eserleri: 389. Ankara: TTK Press.

Beardsworth, A. and Keil, T. (2011), "Yemek Sosyolojisi: Yemek ve Toplum Çalışmasına Bir Davet" (Abdulbaki Dede, Trans.). Phoenix Press: Ankara.

Beşirli, H. (2005), "Politik Sosyalizasyon Arastirmalari ve Politik Sosyalizasyon Sürecinin Bir Unsuru Olarak Kisla". İstanbul Üniversitesi Sosyoloji Konferanslari Dergisi, 251-261.

Beşirli, H. (2010), "Yemek, Kültür ve Kimlik". Millî Folklor 87, 159-169.

Bozkurt, V. (2007), "Değişen Dünyada Sosyoloji: Temeller, Kavramlar, Kurumlar". Bursa: Ekin Press.

Çakır, V. (2005). Konya'nın Geleneksel Eğlence Kültürü. Türkiyat Araştırmaları Dergisi, 17, 355-382.

Çalık, T. (2003), "İşörenlerin Örgute Uyumu (Örgütsel Sosyalizasyon)". Türk Eğitim Bilimleri Dergisi, 2, 163-178.

Çerik, S. and Bozkurt, S. (2010), "Çalışanların Örgütsel Sosyalizasyon ve Kariyer Çabalarına Yönelik Algılamaları Arasındaki İlişkinin Incelenmesi ve Banka Çalışanlarına Yönelik Bir Araştırma”. Erciyes Üniversitesi İlktisadi ve İdari Bilimler Fakültesi Dergisi 35, 77-97.

Çevik, S. and Saçılık, Y., M. (2011), "Destinasyonun Rekabet Avantajı Elde Etmesinde Gastronomi Turizminin Onemi: Erdek Ornegi”. In M. A. Öncü (Eds.), 12.Ulusal Turizm Kongresi Bildiriler Kitabı, 503-515, Düzce: Seher Press.

Childe, V., G. (2010). Kendini Yaratan Insan: Insanın Çağlar Boyu Gelişimi (Filiz Ofluoğlu, Çev.) Istanbul: Varlık Yayınları.

Coştu, Y. (2009), "Toplumsallaşma Kavramı Üzerine Sosyolojik Bir Değerlendirme". Dinbilimleri Akademik Arastirma Dergisi, 9 (3), 117-140.

Dotson, M. J. and Hyatt, E., M. (2005), "Major Influence Factors In Children's Consumer Socialization" Journal of Consumer Marketing, 22 (1), 35 - 42.

Dubow, E. F., Huesmann, L. R. and Greenwood, D. (2006), Media and Youth Socialization: Underlying Processes and Moderators of Effects. In J. Grusec \& P.

Durlu Özkaya, F., Cömert, M. and Kızılkaya, Ö. (2009), "Turizm İşletmelerinde Zeytin Yağlılarımızın Yeri ve Önemi”. 3. Ulusal Gastronomi Sempozyumu, Antalya.

Emiroğlu, K. (2012), "Besin Zinciri Halkaları: Tıynet Tarihi". In Avci, A., Erkoc S., Otman, E. Eds), Yemekte Tarih var Yemek Kültürü ve Tarihçiliği. İstanbul: Tarih Vakfı Yurt Press.

Erbay, K., A. (2006). Popüler Kültür ve Beslenme Biçimleri Örnek Olay: Döner Kebap. Ankara Üniversitesi, Sosyal Bilimler Enstitüsü, Yayınlanmamış Yüksek Lisans Tezi, Ankara.

Ercan, F. (2013), "Toplumlar ve Ekonomiler." Ankara: Bağlam Press.

Ertaş, Y. and Karadağ, G.(2013), "Sağlıklı Beslenmede Türk Mutfak Kültürünün Yeri”. Gümüşhane Üniversitesi Sağlık Bilimleri Dergisi, 2(1), 117-136.

Fichter, J.H. (1973). Sociology. 2nd ed. Chicago: University of Chicago Press 
Güler, S. (2010), "Türk Mutfak Kültürü ve Yeme İçme Alışkanlıklar. Dumlupınar Üniversitesi Sosyal Bilimler Dergisi, 26, 24-30.

Güneş, G., Ülker, H.İ. and Karakoç, G. (2008), "Sürdürülebilir Turizmde Yöresel Yemek Kültürünün Önemi”. II. Ulusal Gastronomi Sempozyumu ve Sanatsal Etkinlikler, Antalya.

Gupta, V. and Krishnan V. R. (2004), "Impact of Socialization on Transformational Leadership: Role of Leader Member Exchange". South Asian Journal of Management, 11 (3), 7-20.

Gürsoy, D. (2014), "Tarihin Süzgecinde Mutfak Kültürümüz”. İstanbul: Oğlak Yayınları. Halıcı, N. (2007), "Mevlevi Mutfağı". Istanbul: Metro Kültür Yayınları.

Horng, J., S. and Tsai, C., T. (2012). "Culinary Tourism Strategic Development: An Asia-Pacific Perspective", International Journal of Tourism Research, 14, 40-55.

Içli, G. (2002). "Sosyolojiye Giriş". Ankara: Anı Yayınları.

İnan, A. (1998), "Makaleler ve İncelemeler (2)”. Ankara: Türk Tarih Kurumu.

Kapağan, E. (2013), "Gök Tanrı İnancı ve Bu İnanç Sisteminin İçinde Alkış, Dua ve Dilekler". Turkish Studies - International Periodical for the Languages, Literature and History of Turkish or Turkic, 9 (3), 801-810.

Kılıç, S. and Albayrak, A. (2012), "İslamiyetten Önce Türklerde Yiyecek ve İçecekler". Turkish Studies - International Periodical for the Languages, Literature and History of Turkish or Turkic, 7 (2), 707-716.

Kosay, H. Z. (1982), "Eski Türklerin Anayurdu ve Yemek Adları". Turk Mutfagi Sempozyumu Bildiriler, Kultur ve Turizm Bakanlığı. MiFAD Editions: 41, Seminer, Kongre Bildirileri Dizisi: 12. Ankara: Ankara Üniversitesi Yayınları, 4756.

Kulmbach, S. R. (2014), "Food Socialization In Early Childhood", Science \& Research, 7, 116-122.

Lin, Y., Pearson, T., E. and Cai, L., A. (2011), "Food as a Form of Destination Identity: A Tourism Destination Brand Perspective". Tourism and Hospitality Research, 11 (1), 30-48.

McKrecher, B., Okumuş, F. and Okumuş, B. (2008), "Food Tourism as a Viable Market Segment: It's All How You Cook the Numbers". Journal of Travel \&Tourism Marketing 25(2), 137-148.

Memduhoğlu, H. B. (2008), "Örgütsel Sosyalleşme ve Türk Eğitim Sisteminde Örgütsel Sosyalleşme Süreci”. Yüzüncü il Üniversitesi Eğitim Fakültesi Dergisi 5(2),137153.

Moschis, G. P. and Churchill, G. A. (1978), "Consumer Socialization: A Theoretical and Empirical Analysis", Journal of Marketing Research, 15 (4), 599-609.

Moschis, G., P., Moore L. R., and Smith, B. R. (1984), "The Impact of Family Communication on Adolescent Consumer Socialization", in NA - Advances in Consumer Research, eds. Thomas C. Kinnear, Provo, UT : Association for Consumer Research, 11, 314-319.

Okumus, B. Okumus, F. and Mckrecher, B. (2007), "Incorporating local and international cuisines in the marketing of tourism destinations: The cases of Hong Kong and Turkey". Tourism Management, 28, 253-261.

Oskay, U. (1974), "Yapısal Bir Sorun Olarak Kültür Değişimi”, Amme Idaresi Dergisi, 7 (1), 80-102.

Özgen, I. (2013). "Uluslararası Gastronomiye Genel Bakış”. In M. Sariisik (Ed.). Uluslararası Gastronomi: Temel Özellikler, Örnek Menüler ve Reçeteler. Ankara: Detay Yayıncılık.

Pelit, E. and Kahyaoğlu M. (2015), "Örgütsel Sosyalizasyon Taktiklerinin İşgorenlerin Kariyer Planlamaları Üzerine Etkisi: Bşs Yıldızlı Otel İşletmelerinde Bir Araştırma”. Ekonomik ve Sosyal Araştırmalar Dergisi, 11 (2), 99-118. 
Petrini, C. (2001), "Slow food: The case for taste". New York: Columbia University Press.

Prot, S., Anderson, C. A., Gentile, D. A., Warburton, W., Saleem, M., Groves, C. L., and Brown, S. C. (2015), "Media as Agents of Socialization". In J.E. Grusec and P. D. Hastings (Eds.), Handbook of Socialization (second edition), 276-300 New York, NY: Guilford Press.

Sağır, A. (2012), "Bir Yemek Sosyolojisi Denemesi Örneği Olarak Tokat Mutfağı". Turkish Studies - International Periodical for the Languages, Literature and History of Turkish or Turkic, 7 (4), 2675-2695.

Sökmen, A. (2007), "Örgütsel Sosyalleşme Sürecinde İşgorenlerin Yöneticilerine Dönük Algıları: Ankara'daki Otel İşletmelerinde Bir Değerlendirme”. Anatolia: Turizm Araştırmaları Dergisi, 18(2), 170-182.

Sürücüoğlu, M. S. ve Özçelik, A.Ö., (2005), Eski Türk Besinleri ve Yemekleri. Türk Mutfak Kültürü Üzerine Araştırmalar 2005. Cilt-12. Türk Halk Kültürünü Araştırma ve Tanıtma Vakfı Yayın No: 34. Ankara: Birlik Matbaacılık. 7-54.

Tapur, T. (2009), "Konya İlinde Kültür ve İnanç Turizmi”. Uluslararası Sosyal Araştırmalar Dergisi, 2(9) , 473-492.

Uzun, Ş. (2015). Bir Kadin Şairin Dilinden Hz. Mevlânâ, Mevlevîlk ve Mesnevî-I Şerif. Uluslararası Sosyal Araştırmalar Dergisi, 8 (37), 266-277.

Van Maanen, J., \& Schein, E. H. (1979). Towards A Theory Of Organizational Socialization. In B. M. Staw (Ed.), Research in Organizational Behavior, 1, 209264. Greenwich, CT: JAI Press

Ward, S. (1974), "Consumer Socialization". Journal of Consumer Research, 1(2), 1-14.

Yeşilorman, M. (2006), "Siyasal Sosyalizasyon Sürecinde Sosyo-Ekonomik Faktörlerin Rolü". Bilig, 36, ss. 1-46.

Yılmaz, N. (2013), "Sosyalleşme Sürecinin Siyasallaşma Boyutu". Uluslararası Yönetim İktisat ve İşletme Dergisi, 9 (19), 319-331.

Yönetimi. Ankara: Detay Yayıncılık.

Zorlu, O and Kara A. M. (2012), "Örgütsel Sosyalizasyon Taktiklerinin Örgütsel Bağlılığa Olan Etkileri: Termal Konaklama İşletmelerinde Bir Arastırma”. Seyahat ve Otel İsletmeciliği Dergisi 7(4), 50-62.

www.semazen.net/sp.php?id=164 Date Accessed: 06.03.2013. 